\title{
At sea: What direction for critical early childhood research?
}

\author{
Mathias Urban
}

Abstract: In this paper I reflect on the dilemma critical early childhood research finds itself in today. In order to distinguish and distance ourselves from the certainties and seemingly unquestionable truths of post-political, mainstream, 'normalised' research and its entanglement with neoliberal agendas and corporate interests, have we rendered ourselves irrelevant in the struggle for social justice that once formed the basis for critical inquiry in our field? What hope can there be to (re-)claim the political in our research, and what new (and old) alliances can we count on?

Keywords: normal science, critical inquiry, political inquiry, critical early childhood research, directivity of critical research.

\section{Scylla and Charybdis: Setting the Scene}

Venturing from their Greek homelands into the unchartered waters of the western Mediterranean and into a world we now refer to as Western Europe, ancient seafarers regularly encountered a rather unpleasant dilemma: should they steer clear of the Italian coast on starboard, to avoid being eaten by a fearsome monster, each of its six heads sporting a triple row of shark like teeth - only to risk being swallowed by an equally unsympathetic character drinking down the waters and vessels, and forcefully belching them out again on the Sicilian port side? Too often, the dilemma proved impossible to solve, as we learn from the fate of Odysseus who lost first his crew to Scylla and then his ship to Charybdis. Today, critical early childhood scholars, researchers, theorists and activists find themselves in similar troubled waters. They are trying hard not to give in to pressures and seemingly inescapable truths 
of an increasingly globalised mainstream early childhood research - a phenomenon referred to in the call for papers to this special issue as 'normaliation' of science in a Kuhnian (Kuhn, 1962) sense. Doing so, they have opened early childhood research to new areas of theory and methodology as they introduced, for example, poststructural thinking in the tradition of Michel Foucault and rhizomatic analysis born out of the philosophy of Gilles Deleuze and Felix Guatarri. More recently, the critical discourse in early childhood appears to be turning its back on its foundations, as both critique and discourse as orienting principles are replaced by new-materialist theories, post-humanist onto-epistemologies and post-qualitative methodologies. I position myself as a political scholar (which refers to my understanding of scholarship and research as intrinsically political practice, not to my limited qualifications in political science) who firmly believes that our role as researchers brings with it the privilege and the responsibility to work towards more just and equitable life experiences for all children and their families. This vantage point leads me to the question I want to explore in this paper: in our individual and collective attempts at distancing ourselves from the monsters that mainstream research in our field has helped to create, are we at risk of losing - or worse, of carelessly abandoning - the transformative, emancipatory element of critical inquiry that aims at changing the world? There is a risk, I argue, of losing critical inquiry in early childhood to an equally dangerous monster trying to drown the entire project in a sea of privileged discourse that is self-referential at best, and borderline narcissistic at worst.

Can we resist the Scylla of mainstream positivism and corporate appropriation, as well as the Charybdis of exclusionary introspection? In doing so, can we draw on what Pedro Sotolongo calls 'the power of marginal notions' (Sotolongo, 2013) to build (global) collective action out of radical (local) perspectivity and multiplicity in early childhood research?

\section{Prologue}

Neither Scylla nor Charybdis was born a gruesome monster. Both started their careers as beautiful princesses. Scylla was transformed by witchcraft by jealous Circe. Charybdis' fate was sealed by a revengeful Zeus in retaliation for appropriating land from the gods.

\section{Scylla}

Surely, ours is a good time to be an early childhood researcher? Over the past decades the first years of children's lives have gained unprecedented 
attention by policy makers, economists and influential international bodies including the Organisation for Economic Cooperation and Development (OECD), the World Bank, the United Nation Educational, Scientific and Cultural Organization (UNESCO) to name only a few (OECD, 2001; OECD, 2006; UNESCO, 2007; World Bank, 2003; World Bank, 2011). A powerful supra-national political entity, the European Union (EU), has realised that the way it frames policies aimed at the youngest children and their families can be a major factor for the overall success (or failure) of the entire macroeconomic project. In consequence, the EU has committed itself to providing all our children with the best start for the world of tomorrow (European Commission, 2011). Around the globe, there are plenty more examples for the turn towards young children, their development and education that has fully entered the political landscape in the 1990s. The successful establishment of early childhood as a crucial item on national and international policy agendas is also a success story for research in our field. In a world where global and local causes, practices and consequences of actions in all areas of human activity have become inseparable, it is important to note that the rise of early childhood research in its dominant form can itself be read as a story of local to global projections. Much of the prominence of early childhood on policy agendas derives from a broad consensus that the early years of life are unique in terms of human development. Therefore, what children experience in their first five years will somehow lay the Strong Foundations (UNESCO, 2007) for successful development, learning, and achievement over the entire life course. This consensus is further reflected in a hierarchical conceptualisation of learning and development in steps or stages that have to be mastered in chronological order, and deeply embedded in a discourse that emphasises the importance of Lifelong Learning (Commission of the European Communities, 2005; European Commission, 2000; LLL, 2010, 2007; Word Bank, 2003).

Mainstream early childhood research has played a major role in building this consensus. Over the years, large-scale studies have provided policy makers with the arguments that underpin policies and strategies aiming to 'increase participation in early childhood education and care' as a matter of urgency:

High quality ECEC is beneficial for all children, but particularly for those with a socioeconomically disadvantaged, migrant or Roma background, or with special educational needs, including disabilities. By helping to close the achievement gap and supporting cognitive, linguistic, social and emotional development, it can help to break the cy- 
cle of disadvantage and disengagement that often lead to early school leaving and to the transmission of poverty from one generation to the next. (Council of the European Union, 2011)

That 'high quality' early childhood education and care is not only an effective and beneficial way of achieving ambitious policy goals, but also a cost-effective one, is a central argument supported by mainstream early childhood scholarship. It is, as Stephen Barnett argues, the key to evidence-based policy that improves returns (Barnett, 2010). The title of Barnett's report to the OECD is a good example of mainstream early childhood research adopting the language of mainstream policy. This, of course, is not a phenomenon specific to early childhood scholarship. From a pragmatic or realist perspective it has been argued across a wide range of academic disciplines that we [...] need to learn to speak in terms policymakers understand' (Potomac Institute for Policy Studies, 2013). The authors elaborate their basic argument into four recommendations for members of the academic community who are trying to make their arguments heard by policy makers:

Scientists need to be able to take a step (or five steps) back from their immediate research and articulate the global impact of their field. Communicate the impact in terms that focus on society rather than on science.

Articulate how the science will affect the general public today and five to ten years in the future; this is what matters to policy makers. Policymakers are overworked addressing the issues of today, much less tomorrow. [...]

Write backwards. Policymakers need the conclusions and message up front; justification can follow. [...] Policymakers have limited time so tell them up-front what you're trying to say and justify yourself later. $[\ldots]$

Explore recommendations outside of "provide more funding for my project." Just studying the problem more is neither the most satisfying nor often the most appropriate policy option. Recommend policy and law that directly address the issues at hand. (ibid)

Such an approach is firmly grounded in a paradigm of causality and certainty, and the practices it encourages are questionable, to say the least (articulate global impact-recommend policy-justification can follow). It is an 
excellent illustration of Michel Foucault's notion of discourse: 'practices that systematically form the objects [and subjects, I would like to add] of which they speak' (Foucault, 1972, p. 49). But as discourses converge, boundaries blur between agendas, interests and aims, and it becomes difficult, if not impossible, to ask critical questions. In the case of mainstream early childhood research, the converged discourse rests on a number of taken for granted concepts: that provision of 'high quality' services is beneficial for all children, that there is an 'achievement gap' between children of dominant and marginalised groups in society, that 'closing the gap' will alleviate poverty and in the course of doing so, resolve major economic failures of capitalist society. As I have discussed in more detail elsewhere (Urban, 2016b), this narrative is highly problematic for several reasons:

- Quality, despite being a concept that is either strongly contested (Cannella et al., 2016; Dahlberg et al., 1999; Dahlberg et al., 2007; Penn, 2011; Urban, 2016a; Jones et al., 2016) or rendered irrelevant for the challenges facing early childhood (Moss, 2016).

- The 'lived experience' (Van Manen) of children from the most marginalised communities challenges the claim that increased participation in early childhood education and care (an explicit aim of EU policies) is universally beneficial (Bennett, 2012; Šikić-Mićanović et al., 2015).

- The supposed achievement gap points to an increasingly narrow understanding of learning and development, orienting early childhood services ever closer toward achieving school-readiness as their foremost goal.

- Strategies aimed at closing the gap are grounded in systematic bias against knowledge(s) and child rearing practices that outside of dominant, Western, middle-class worldviews (Ng'asike, 2011; Nsamenang, 2004; Pence \& Marfo, 2008; Penn, 2005).

- Poverty is continuously used as a self-referential concept, with the intergenerational cycle of poverty seen as an intrinsic characteristic of the poor, to which they actively contribute by passing it on from one generation to the next. Such a narrative (which sees inequality and poverty as inevitable) effectively prevents us from asking critical questions about societal conditions that produce, reproduce and maintain inequality and poverty not so much as a result of but as a requirement for capitalist economy (Urban, 2016b, p. 405). 
In early childhood, the mainstream research/policy conversation has developed a coherent narrative that rests on extrapolated (some would say exaggerated, see Derman-Sparks in this volume) experiences in a relatively small scale local early childhood programme in an impoverished Black American community in Ypsilanti, Michigan. The original protagonists of the project have long claimed the 'beneficial effects of ECD [Early Childhood Development, M.U.] programs on young children who are living in poverty and otherwise potentially vulnerable to failure in school' (Schweinhart, 2006, p. 67). However, the claim gained global prominence through the work of economist James Heckman. The Nobel Laureate draws on Human Capital theory as he comes to the economic conclusion that 'investment' in early childhood programmes lead to high 'returns' at a one to seven ratio (Heckman, 2006). In their attempts to connect to dominant policy discourses, many from inside the early childhood field have taken on his argument. However, as sociologists Hilary and Steven Rose point out, it is

a fine claim in the abstract, but it ignores the reality of typical US social policy in which pioneering projects of higher quality are frequent, and indeed attract international interest. But are rarely generalized out at the level of an individual state, let alone across the nation. (Rose \& Rose, 2016, p. 64)

In any case, the Human Capital argument has been, and continues to be, a powerful driver of investment in early childhood programmes around the globe. But, just as beautiful princess Scylla was transformed into a monster by Circe the witch, uncritical readings of Human Capital Theory have supported and accompanied a surge in private-for-profit activities in early childhood globally. This in itself is not a new development. Corporatisation of early childhood services and free market regimes have a long history in many countries. Authors including Helen Penn and Eva Lloyd in the UK (Lloyd \& Penn, 2012) and Frances Press and Christine Woodrow in Australia (Press \& Woodrow, 2005, 2009) have written about the risks to quality and equality of services, and to entire national childcare systems (in the case of the collapse of ABC Learning Ltd.), and even the OECD have expressed their concern:

In many OECD countries, the level of regulation of services for children under 3 gives rise for concern: much of the child care sector is private and unregulated, with staff training and pedagogical programming being particularly weak. (OECD, 2006, p. 14) 
In recent years, however, privatisation and corporatisation of education has expanded on an unprecedented scale and, as Adamson, Astrand and Darling-Hammond (2016) show, private interests have come to dominate the education system to an extent that undermines its purpose. Privatisation, they argue, adversely affects the right to education. Their findings resonate with Tan's (2014), in his detailed critique of Human Capital Theory, succinctly points out with reference to the work of Nussbaum (2010) and Ball (2010):

Education is no longer conceived as an integrated strategy to promote freedom, self-enrichment, and human development, but rather it is a business activity driven by profit or a commodity in the market. (p. 429)

What should alert us about these developments is not only the open pursuit of profit interests in a sector that should be foremost a public responsibility and public good. It is a real matter of concern that the project of early childhood research speaking the language of policy makers in order to gain attention and influence is over. We have entered a post-political era where the interests of lead actors (i.e. OECD, World Bank, and increasingly venture-philanthropy) go hand in hand with the interests of global education corporations. As the business magazine Forbes reminds us, 'Education is a trillion dollar industry and it will take 2 decades to enable the industry to reach to major inflection point' (Viswanathan, 2014).

\section{Charybdis}

In the face of an increasingly powerful global alliance between mainstream research - Big Social Science (Torrance, 2015) - , neoliberal policy agendas, and corporate interests, critical scholars have systematically been marginalised. Reflecting on the 'historical present' of critical qualitative inquiry, Norman Denzin and Michael Giardina (2016) come to the following conclusion:

especially those scholars in the humanities and social sciences doing critical, feminist, poststructural, postmodern, and posthuman research face a crossroads, one in which (a) the act of research is inherently political; (b) that act is governed by a particular free-market politics of research in the corporate university; (c) (post-)positivism still dominates this conversation; and (d) anti-foundational approaches to research are often marginalized [...]. (p. 5) 
Critical early childhood scholars have been trying hard to carve out, and protect spaces of resistance against the political and onto-epistemological monster. Within these spaces, they have been not stopped to question seemingly unquestionable thruths and the 'rules of the game' that a normalised - in a Kuhnian (1962) sense - early childhood research has become. Internationally, they have built a community of scholars and supportive spaces that have allowed opening early childhood research to new areas of theory, philosophy and methodology. Michel Foucault's work has provided us with the necessary tools for understanding the workings of power in all our understandings, conceptualisations and actions (e.g. Mac Naughton, 2005). Drawing on the writing of Gilles Deleuze and Felix Guatarri, non-linear, rhizomatic thinking has shaped our analyses and practices (e.g. Olsson, 2009). More recently, feminist/queer, new-materialist and posthuman work, inspired by writers like Rosi Braidotti (2002; 2011), Karen Barad (2007) has further challenged our understandings of what research might mean when mind/meaning/matter/agency / can no longer be separated or attributed to distinct Cartesian researcher-subjects. They all contribute to a shared history, going back to the late 1970s, of 'asking questions about the narrow perspectives of the dominant empirical research in child development/ECE in research in the United States and in Great Britain, Australia, Northern, Western, and East-Central Europe, Latin America, Asia, and Africa' (Bloch et al., 2014a, p. 3). The emerging critical work eventually found its home in the international Reconceptualising Early Childhood Education (RECE) group, which held its first conference at the University of Wisconsin-Madison in 1991. At the time of writing this paper, we are preparing for the $24^{\text {th }}$ international RECE conference, to be held in Aotearoa/New Zealand in autumn 2016. Measured in terms of new and unconventional thinking, sustained critical debate and scholarly 'output', the mission to reconceptualise our inquiries, understandings and practices concerning young children has surely been successful - as documented, not least, in an edited volume in 2014 (Bloch et al., 2014b). It is in his contribution to this book that Michael O'Loughlin (O'Loughlin, 2014, p. 63, see also in this volume) recalls a sense of 'nurturance, hope, possibility, and a perpetual wish for more' at the very heart of the RECE movement. He also wonders for what, if anything, RECE and its critical contributors will be remembered in a world of predatory capitalism, ruthless mechanical notions of accountability, and disinterest in the existential and liberatory potential of care and education' (ibid). O'Loughlin's question is one that the neoliberal, corporate university, in techno-managerial speak, regularly frames as impact: Have we had 'any lasting influence on policy and practices?' (ibid). The answer, on a global scale, is not encouraging. Together with Michael O’Loughlin, we are 'still waiting for the revolution' (ibid). 
The apparent lack of impact is an interesting - and worrying - parallel between mainstream 'normal' science and the movement that set out to overcome its limitations. Especially for the most marginalised children, life situations have hardly improved and growing up under what some used to call (arrogantly) third world conditions has become the new normal for an increasing number of children in the most affluent countries (Lansley \& Mack, 2015; Šikić-Mićanović et al., 2015; Urban, 2015; 2016b). However, there are crucial differences between the two sides as well: While the effects in relation to the broad claims - reduction of poverty and inequality, social cohesion etc. - have been questionable at least, the mainstream narrative has clearly had a strong impact on policies and practices. This, according to its own accounts, is not the case for the critical inquiry camp.

Having been involved with critical scholarship in early childhood for most of my professional and academic career (including publications, projects of collaborative inquiry, organising and hosting RECE conferences and many other activities) I am well aware of the marginalisation of smallscale, mostly qualitative, and usually un- or under-funded research in the corridors of power. But I also have come to believe that proactive exclusion and disregard by policy makers and research councils is only one aspect (albeit a highly effective one) of a more complex picture. Faced with a hostile external environment, critical early childhood inquiry has circled the wagons and entered a phase of introspection. At conferences and seminars, there has always been a tendency of talking to ourselves rather than the outside world. This is understandable and necessary because mutual support and solidarity are, in my view, the foundations of critical inquiry. But as a result, were we more concerned with analysing policy than actually making it?

There is a second critical aspect of the situation critical early childhood inquiry finds itself in: The initial raison d'etre for the movement was to critique (and promote alternatives to) a positivist, conservatively developmental, and politically hegemonic mainstream. This, however, seems to have changed to some extent, and the critique turned inward. It is, at least, one possible reading of the rising number of contributions to the discussion that situate themselves in a post-qualitative (Lather $\&$ St. Pierre, 2013) paradigm or 'turn away from methodology altogether' (Denzin \& Giardina, 2016, p. 5). We have entered unknown waters: a post-critical, Latourian (Latour, 2004) mare incognitum, not yet reframed with a new ethics 'of ethical accountability in the sense of a fundamental reconfiguration of our being in the world that is ethnically diverse, technologically and globally mediated, and fast 
changing' (Braidotti, 2011, p. 301). It is urgent, Braidotti continues to argue, that we find 'new and alternative modes of political and ethical agency' (ibid).

\section{Where to from here (a tentative map)}

Talking about the purpose of education (and insisting on the impossibility of a purpose-free education), Paulo Freire introduces the concept of directivity:

The directivity of education means that education starts from a given level and goes beyond itself. It also means that education has always implicit utopias, dreams, desires and values. I cannot simply say: 'I educate for nothing'. Teachers insist on being teachers, this means they have a kind of dream'. (Figueiredo-Cowen \& Gastaldo, 1995, p. 18)

Critical inquiry in our field needs a similar understanding of its purpose. We cannot inquire for nothing and we urgently need to go beyond the selfreferential conversation. Our conversations, instead, should be facing outward - and they should be centred around our utopias, dreams, desires and values which we need to move from the implicit to the explicit. This conversation will be controversial, as it would be naïve to pretend that there can be one dream, one set of values, one utopia we all share. But to engage in that conversation, and to proactively initiate it within and, most importantly beyond our community of critical early childhood scholars will be a crucial step in a necessary search for 'new and alternative modes of political and ethical agency', and to confront the 'inertia or self-interest of neoconservative thought' (Braidotti, 2011, p. 301). It will require our concerted efforts to (re-)politicise our research. Citing Leslie Bloom and Patricia Sawin (Bloom \& Sawin, 2009, pp. 338, 340-342, 344), Norman Denzin (2015) suggests five goals for critical qualitative inquiry that can serve well for a preliminary orientation of the project of a re-politicised early childhood inquiry:

1. Place the voices of the oppressed at the center of the inquiry;

2. Use inquiry to reveal sites for change and activism;

3. Use inquiry and activism to help people;

4. Affect social policy by getting critiques heard and acted on by policy makers;

5. Affect change in the inquirer's life, thereby serving as a model. (Denzin, 2015, p. 33) 
There are new, emerging alliances we can build on, as well as some old and perhaps not so obvious ones. New-materialist, feminist and posthuman thought, for instance, resonates with the work of indigenous scholars from around the world. It offers the possibility to go beyond the confines of Cartesian dualism that has left us, in the Western, minority world, with a notion of a child whose mind, body, spirituality are disconnected from each other and from their being in the world. It will be important, however, that we aware of the risk of our silencing indigenous scholarship and activist voices through new layers of white, privileged discourse and onto-epistemological neo-colonialism in order to gain academic distinction. Required are geohistorical modesty and acknowledgement of origin:

Indigenous ontologies never had a nature-culture dualism, never truly differentiated nature and culture. (Jones \& Hoskins, 2016, p. 79)

Writing this from the perspective of an academic based at an interdisciplinary research centre that grounds it work in the philosophy and pedagogy of Friedrich Froebel (1782-1852), the pioneer of the Kindergarten, I want to conclude with an offer for another possible, and, I believe, necessary alliance. Post-humanist thinker Karen Barad writes: 'Matter feels, converses, suffers, desires, yearns and remembers' (2012, p. 59). Nearly 200 years earlier, Friedrich Froebel places unity of the human, non-human and spiritual world at the centre of his pedagogy:

When he is at play a child talks continuously, thus indicating that with him talking is not yet distinguished from himself as talker, nor names from the things named. Play and speech are the elements in which the child now lives. So he attributes the same life to all about him. The pebble, the chip of wood, the plant, the flower, the animal each and all can hear and feel and speak.

In childhood there is a four-fold development of life - the child's own inner life; his life in relation with parents and family; his life in relation, common to him and them, with a higher invisible Being; and, especially, his life in relation with nature, regarded as endowed with life like his own. (Froebel, 1826 [1912], p. 50, emphasis added)

But besides being the first post-humanist thinker in early childhood, Froebel also placed his pedagogy in the context of a dramatically changing society in early $19^{\text {th }}$ century Europe. The political climate was one of civil rights movement (1833) and revolution (1848). Early childhood education 
for all, Froebel insisted, was a public good and responsibility, and one of the preconditions for the democratic republic the 1848 revolutionaries aimed to build. No wonder, then, that after the collapse of the revolution the powers of State banned Froebel's Kindergarten for being atheist, socialist and outright dangerous. This is a proud legacy for early childhood scholarship, and it is our responsibility to carry on with the struggle.

\section{References}

Adamson, F., Astrand, B., \& Darling-Hammond, L. (2016). Global education reform: How privatization and public investment influence education outcomes. New York: Routledge.

Ball, S. J. (2010). New voices, new knowledges and the new politics of education research: The gathering of a perfect storm? European Educational Research Journal, 9(2), 124-137.

Barad, K. (2007). Meeting the university halfway: Quantum physics and the entanglement of matter and meaning, Durham, NC: Duke University Press.

Barad, K. (2012). Interview. In: R. Dolphijn, \& I. Van Der Tuin (Eds.), Ann Arbor: Open Humanities Press.

Barnett, S. W. (2010). Benefits and costs of quality per-school education: Evidence based-policy to improve returns. Paper presented at the 7th OECD ECEC network meeting.

Bennett, J. (2012). Roma early childhood inclusion: The RECI Overview Report. Budapest: OSF/REF/UNICEF.

Bloch, M., Swadener, B. B., \& Cannella, G. S. (2014a). Exploring reconceptualist histories and possibilities. In: M. Bloch, B . B. Swadener, \& G. S. Cannella (Eds.), Reconceptualizing early childhood care and education: Critical questions, new imaginaries and social activism: a reader (pp.1-18). New York: Peter Lang.

Bloch, M., Swadener, B. B., \& Cannella, G. S. (2014b). Reconceptualizing early childhood care and education: Critical questions, new imaginaries and social activism: $A$ reader. New York: Peter Lang.

Bloom, L. R., \& Sawin, P. (2009). Ethical responsibility in feminist research: Challenging ourselves to do activist research with women in poverty. International Journal of Qualitative Studies in Education, 22(3), 333-351.

Braidotti, R. (2002). Metamorphoses: Towards a materialist theory of becoming, Cambridge: Polity Press.

Braidotti, R. (2011). Nomadic theory : The portable Rosi Braidotti. New York: Columbia University Press.

Cannella, G. S., Salazar Pérez, M., \& Lee, I.-F. (2016). Critical examinations of quality in early education and care. Regulation, disqualification and erasure. New York: Peter Lang.

Commission of the European Communities. (2005). Towards a european eualifications framework for lifelong learning. Commission staff working paper. Brussels. Council of the European Union. (2011). Council conclusions of 15 June 2011 on 
early childhood education and care: Providing all our children with the best start for the world of tomorrow. Brussels: Official Journal of the European Union.

Dahlberg, G., Moss, P., \& Pence, A. (1999). Beyond quality in early childhood education and care. Postmodern perspectives. London: Falmer.

Dahlberg, G., Moss, P., \& Pence, A. R. (2007). Beyond quality in early childhood education and care : Languages of evaluation. New York: Routledge.

Denzin, N. K. (2015). What is critical qualitative inquiry? In G. S. Cannella, M. S. Pérez, \& P. A. Pasque (Eds.), Critical qualitative inquiry: Foundations and futures (pp. 31-50) . Walnut Creek, CA: Left Coast Press, Inc.

Denzin, N. K., \& Giardina, M. D. (2016). Qualitative inquiry through a critical lens, New York and London: Routledge.

European Commission. (2000). A memorandum of lifelong learning. Brussels: EC.

European Commission. (2011). Early childhood education and care: Providing all our children with the best start for the world of tomorrow. Brussels: European Commission, Directorate General for Education and Culture.

Figueiredo-Cowen, M., \& Gastaldo, D. (Eds.) (1995). Freire at the institute. London: Institute of Education.

Foucault, M. (1972). The archeology of knowledge. New York: Pantheon.

Froebel, F. (1826 [1912]). Froebel's chief writings on education (Rendered into English). London: Edward Arnold.

Heckman, J. J. (2006). Skill formation and the economics of investing in disadvantaged children. Science, 312(5782), 1900-1902.

Jones, A., \& Hoskins, T. K. (2016). A mark on paper: The matter of indigenous settler history. In C. A. Taylor, \& C. Hughes (Eds.), Posthuman research practices in education (75-92). New York: Palgrave Macmillan.

Jones, L., Urban, M., Osgood, J., \& Holmes, R. (2016). Reimagining quality in early childhood. Contemporary Issues in Early Childhood, 17(1), 1-5.

Kuhn, T. S. (1962). The structure of scientific revolutions. Chicago: University of Chicago Press.

Lansley, S., \& Mack, J. (2015). Breadline Britain. The rise of mass poverty. London: Oneworld.

Lather, P., \& St. Pierre, E. A. (2013). Post-qualitative research. International Journal of Qualitative Studies in Education, 26(6), 629-633.

Latour, B. (2004). Why has critique run out of steam? From matters of fact to matters of concern. Critical Inquiry, 30(Winter 2004), 225-248.

LLL 2010. 2007. The European Union's lifelong learning policies: A review [Online]. Available: http:/ /LLL2010.tlu.ee

Lloyd, E., \& Penn, H. (2012). Childcare markets: Can they deliver an equitable service? Bristol: Policy.

Mac Naughton, G. (2005). Doing Foucault in early childhood studies: Applying poststructural ideas. London: Routledge.

Moss, P. (2016). Why can't we get beyond quality? Contemporary Issues in Early Childhood, 17(1), 8-15.

Ng'asike, J. T. (2011). Turkana children's rights to education and indigenous knowledge in science teaching in Kenya. The New Zealand Journal of Teachers' Work. 8(1), 55-67. 
Nsamenang, A. B. (2004). Cultures of human development and education: Challenge to growing up African. New York: Nova Science Publishers.

Nussbaum, M. C. (2010). Not for profit: Why democracy needs the humanities. Princeton, N.J.: Princeton University Press.

O'Loughlin, M. (2014). Still waiting for the revolution. In M. Bloch, B. B. Swadener, $\&$ G. S. Cannella (Eds.), Reconceptualizing early childhood care and education: Critical questions, new imaginaries and social activism: A reader (pp. 63-76). New York: Peter Lang.

OECD. (2001). Starting strong. Early childhood education and care. Paris: OECD.

OECD. (2006). Starting strong II. Early childhood education and care. Paris OECD.

Olsson, L. M. (2009). Movement and experimentation in young children's learning: Deleuze and Guattari in early childhood education. London: Routledge.

Pence, A. R., \& Marfo, K. (2008). Early childhood development in Africa: Interrogating constraints of prevailing knowledge bases. International Journal of Psychology, 43(2), 78-87.

Penn, H. (2005). Unequal childhoods. Young children's lives in poor countries. London: New York: Routledge

Penn, H. (2011). Quality in early childhood services : An international perspective. Maidenhead: McGraw-Hill/Open University Press.

Potomac Institute for Policy Studies. (2013). Speak Policy. CReST Blog [Online]. Available from: https://potomacinstituteceo.wordpress.com/2013/12/09/speak-policy.

Press, F., \& Woodrow, C. (2005). Commodification, corporatisation and children's spaces. Australian Journal of Education, 49(3), 278-291.

Press, F., \& Woodrow, C. (2009). The giant in the playground: Investigating the reach and implications of the corporatisation of childcare provision. In D. King, \& G. Meagher (Eds.), Paid care in Australia: Politics, profits, practices (pp. 231-254). Sydney: Sydney University Press.

Rose, H., \& Rose, S. P. R. (2016). Can neuroscience change our minds? Cambridge: Malden, MA, Polity.

Schweinhart, L. J. (2006). Outcomes of the high/scope Perry preschool study and Michigan school readiness program. World Bank.

Šikić-Mićanović, L., Ivatts, A. R., Vojak, D., \& Geiger-Zeman, M. (2015). Roma early childhood inclusion. Croatia report. London: Open Society Foundations.

Sotolongo, P. (2013). Idea-forces: The power of marginal notions. East-West Affairs: A Quarterly Journal of North-South Relations in Postnormal Times [Online]. Available: https:/ / eastwestaffairs.files.wordpress.com/2014/01/ewa2-final1.pdf.

Tan, E. (2014). Human capital theory: A Holistic criticism. Review of Educational Research, 84(3), 411-445.

Torrance, H. (2015). Investigating research power: Networks, assemblages, and the production of 'big' social science. In G. S. Cannella, M. S. Pérez, \& P. A. Pasque (Eds.), Critical qualitative inquiry: Foundations and futures (pp. 265-280). Walnut Creek, CA: Left Coast Press, Inc.

UNESCO. (2007). Strong foundations. Early childhood care and education. Education for all global monitoring report 2007. Paris: UNESCO.

Urban, M. (2015). From 'closing the gap' to an ethics of affirmation. Reconceptualis- 
ing the role of early childhood services in times of uncertainty. European Journal of Education, 50(3), 293-306.

Urban, M. (2016a). Starting wrong? The trouble with a debate that just won't go away. In G. S. Cannella, M. Slazar Pérez, \& I. F. Lee (Eds.) Critical examinations of quality. regulation, disqualification and erasure (pp.85-104) . New York: Peter Lang. Urban, M. (2016b). Sufficiently well informed and seriously concerned? European Union policy responses to marginalisation, structural racism and institutionalised exclusion in early childhood. Alberta Journal of Educational Research, 61(4), 399416.

Van Manen, M. (1990). Researching lived experience: Human science for an action sensitive pedagogy. State University: New York Press.

Viswanathan, B. (2014). What are the 10 bilions big industries of the future. [Online]. In Forbes, May, 2014. Available: http://www.forbes.com/sites/quora/2014/05/14/ what-are-the-10-billion-big-industries-of-the-future/\#6076994761f7

World Bank. (2003). Lifelong learning in the global knowledge economy : Challenges for developing countries, Washington, DC: World Bank.

World Bank. (2011). Learning for all. Investing in people's knowledge and skills to promote development. World bank group education strategy 2020. Washington DC: World Bank.

\section{Author:}

Mathias Urban, professor

University of Roehampton

Early Childhood Research Centre

School of Education

Roehampton Lane

SW15 5PU

London

UK

Email: mathias.urban@roehampton.ac.uk 